\title{
Environmental Reporting and Sustainbility Reports in Oil Companies in Nigeria
}

\author{
Joseph U. Madugba ${ }^{1}$, E. Ben-Caleb ${ }^{1}$, T. U. Agburuga ${ }^{2}$, W. C. Ani ${ }^{3}$, S. L. Jegede ${ }^{4} \&$ S. O. Fadoju ${ }^{5}$ \\ ${ }^{1}$ Accounting and Finance Department, Landmark University, Omu Aran, Kwara State, Nigeria \\ ${ }^{2}$ Bursar and Senior Lecturer, Federal University, Otuoke, Bayelsa State, Nigeria \\ ${ }^{3}$ Banking and Finance Department, Michael Okpara University Umudike, Umuahia, Nigeria \\ ${ }^{4}$ University of Silesia, Katowice \\ ${ }^{5}$ Bursary Department, landmark University, Kwara State, Nigeria \\ Correspondence: Joseph U. Madugba, Accounting and Finance Department, Landmark University, Omu Aran, \\ Kwara State, Nigeria. E-mail: joeugochukwu@yahoo.com
}

Received: April 17, 2020

Accepted: May 25, 2020

Online Published: January 9, 2021

doi:10.5430/ijfr.v12n1p310

URL: https://doi.org/10.5430/ijfr.v12n1p310

\begin{abstract}
Environmental reporting is crucial for corporate survival as it builds corporate image, but certain procedures and regulations must be put in place to guide such reporting. Accordingly, this study examined environmental reporting and sustainability reports by oil companies in Nigeria with the aim of assessing the relationship between corporate environmental reporting and determinant of sustainability reports. Ex-post-facto and survey research design were adopted and data were sourced from structured questionnaires administered to corporate respondents and a 56 item sustainability reporting index adapted from the Global Reporting Initiative. Descriptive statistics were carried out, one way and two factors ANOVA and Post hoc test were all conducted. The study provided evidence of a positive and significant variation between corporate environmental reporting and determinants of sustainability reports in petroleum companies in Nigeria. The study recommended that management of petroleum companies should ensure compliance with corporate sustainability reporting.
\end{abstract}

Keywords: environmental reporting, sustainability reports, reporting indicators, Nigeria

\section{Introduction}

Green politics is both a communal and economic imperative for the modern world. Environmental reporting is a medium through which corporate environmental issues are communicated. Over the decades, there has been increasing debate regarding environmental management world over mainly based on natural degradation initiated by economic development.

The importance of transparency and disclosure in environmental reporting cannot be overemphasized as it has engrossed international communities and environmental bodies for its role. Hence corporations all over the world are now motivated to report their activities and practices in particular concerning the environment (Islam 2010). Reference to petroleum companies has shown that environmental calamities emanating from environmental issues, such as oil spillage, etc causes disasters to the surrounding environment and raised worries from the public especially communities where such companies operate (Cormier, Magnan \& Van Velthoven 2005; Islam 2010, Uwaoma and Ordu 2016, Nwobu 2017).

Inability to checkmate and regulate oil explorative actions of these companies will not only manifest in severe and avoidable environmental harm but May also, metamorphose to severe health hazards. Again, the cultures, economic and social structure of local and indigenous communities are often affected. To make matters worse, environmental laws in emerging economies like Nigeria are grossly ineffective and substantively inadequate partly because they are inadequately enforced (Nwobu, 2017).

It is expedient to state that sustainability reporting is a valuable tool for managing and measuring the progress of petroleum companies. This is because it is a strategy for constructive stakeholder engagement which fosters harmonious alignment of stakeholder's concerns. This paper sheds light on the adequate Environmental Reporting both financial and non-financial and its importance in the industry in reaching out to stakeholders.

Various merits have been identified as cogent for firms' involvement in sustainability reports among them are: 
1. It enhances competitive advantage: usually organization that engages in environmental and sustainability reporting is perceived by stakeholders as not harnessing the environment but also seeing to well-being of the people hence gain competitiveness among others. (Jones, 2010).

2. Sustainability reporting builds corporate image: Socially and environmental friendly firms are graded to have good corporate image and this leads to improve performance.

3. The attraction of more capital: sustainability responsive firms are perceived to be contributing and positively influencing the environment where they operate and when sourcing fund from the capital market investors are attracted to patronize them (Murray et al., 2006; Kwanbo, 2011, Madugba, et al 2020).

\section{Theoretical Framework for Sustainability Reporting}

This work receives theoretical support and justification from the legitimacy and stewardship theories. The legitimacy theorist upholds that there is a social bond connecting an entity and its constituents, in which "organization agrees to undertake various communally desired actions in return for endorsement of its objectives, other rewards and ultimate survival" (Guthrie and Parker, 1989). Under this perspective, organizations would employ numerous legitimate means to shield their legality (Ashforth and Gibbs, 1990; Suchman, 1995) and be in charge for prospective apparent legitimacy gaps.

Stewardship theory is also crucial when discussing environmental reporting and sustainability reports because firms ought to fashion their goals to include the stakeholders as they have interest in the firm Khan, Hussain, Ur-Rehman, Maqbool, Ali and Numan (2019). The responsibility of a firm is not just to make a profit but also to satisfy interest groups that have a claim in the firm Asogwa, Ofoegbu, Nnam, and Chukwunwike (2019) Johl and Khan (2019). This study adopted both theories because both centers on the relationship between the firm and the environment where it exist.

\subsection{Empirical Literature Review and Hypotheses Development}

Effective corporate reporting mechanism entails the integration of sustainability report into the annual reports. Corporate accountability is not in view without a sustainability report, thus necessitating the need for sustainability reports and it's disclosing to be incorporated. Sustainability reports may be published as stand-alone reports or incorporated into corporate annual reports. In Nigeria, this received attention. Permitting voluntary reporting by petroleum companies in Nigeria especially as there is no strong legislation stipulating what should be reported (Asaolu, Agboola, Ayoola \& Salawu, 2011). Nigeria as a nation is yet to determine the how, nature and standard of sustainability reporting as well as its conformity with the international community.

Parve and Satirenjit (2019) in a study on nexus of comprehensive green innovation, environmental management system- 14001-2015 and firm performance found that implementation of a comprehensive green innovation will manifest in reduction of production cost, minimization of resource consumption and improve the performance of firms.

Ofoegbu, Odoemelam and Okafor (2018) using data extracted from annual reports of 303 companies both in Nigeria and South Africa found that greater number of companies in both countries influences environmental disclosures.

Analysis of sustaibility reporting practice in mining, oil and gas companies in Indonesia (GRI guidelines approach) was investigated by Permatasari in 2018. The study found that there is an increasing trend of sustainability reporting practices, but environmental, social and economic indicators are consistently increasing while other indicators are missing.

In like manner, Cheema and Javed (2017) reported that rising demand for CSR motivated the application of management tools for green human resource management which most organizations have adopted. The paper concluded that effective CSR improves sustainable environment.

Martina and Emma (2016) examined how sustainability reporting has changed in the oil and gas industry in Europe and how the companies have followed the GRI guidelines. The study adopted quantitative method and content analysis, and found that companies have increased their level of compliance but there is difference in level of compliance amongst the companies.

Ismail and Rahman (2016) found that the quality of environmental disclosure of the sample companies is relatively high compared to previous studies. This study, however, failed to identify the measures of quality of environmental reporting adopted in the study. Their finding is supported by Eljayash, James and Kong (2012), Eljayash, Kavanagh, and Kong1 (2013), and Sulaiman, Abdullah, and Fatima (2014). These studies are not in Nigeria. The study of Uwaoma and Ordu (2016) lack quantitative proof as it was more of expressions hence cannot be relied on.

Schneider, et al (2013) in their study found environmental, health and safety of oil and gas companies in United Kingdom and the US to be in the middle/medium level of maturity but with significant gap in performance. Implying 
that sector has made progress by embracing sustainability, but still have to do more especially in compliance to clean Air Act, Spill and progress management.

The above gaps necessitated the urgent need to find out the variation between corporate sustainability reporting and environmental reporting in oil companies in Nigeria, with the hypotheses

H0: The variation between corporate sustainability reporting and environmental reports in oil companies in Nigeria between 2014 and 2018 is not significant.

\section{Research Methods}

This study adopted the survey and longitudinal research designs. The survey was used to extort data from annual reports and the stand-alone reports, while the longitudinal was used because repeated observations of the same units (oil and gas companies in this study) over a period of time were utilized. Ssekiyivu, Mwesigwa, Bananuka, and Namusobya (2018) adopted survey design in a similar study. Sustainability reports were measured with a 56 item of GRI. Meek, Robert \& Gray (2006), Nwobu (2017) and Cyriac (2013) adopted same measure for sustainability reporting. In this study, indicators for sustainability reporting adopted are thus: economic, environmental, social and governance. The views of the corporate respondents on factors influencing sustainability reporting and the performance attached to such factor were ascertained with the survey. The population of this study is made up of 14 petroleum companies (Directory of the Nigerian Stock Exchange, 2015). Purposively nine companies were selected base on availability and the nature of data required for this study.

\section{Empirical Result and Discussion}

The results of the study are presented in Tables $1-4$ and Figure 1. Some descriptive statistics such as the minimum, maximum, variance, mean, skewness, kurtosis and their standard error as applicable are presented in Table 1.

Table 1

\begin{tabular}{|c|c|c|c|c|c|c|c|}
\hline $\begin{array}{l}\text { Sustainability } \\
\text { variables }\end{array}$ & Year & Min & $\operatorname{Max}$ & Var & Mean \pm SE & Skew \pm SE & Kurt \pm SE \\
\hline \multirow{5}{*}{$\begin{array}{l}\text { ECOIND }(\mathrm{n}= \\
15)\end{array}$} & 2014 & 0.00 & 9.00 & 13.171 & $5.200 \pm 0.937$ & $-0.186 \pm 0.580$ & $-1.725 \pm 1.121$ \\
\hline & 2015 & 1.00 & 9.00 & 13.029 & $5.800 \pm 0.932$ & $-0.612 \pm 0.580$ & $-1.638 \pm 1.121$ \\
\hline & 2016 & 1.00 & 9.00 & 10.171 & $5.800 \pm 0.823$ & $-0.339 \pm 0.580$ & $-1.651 \pm 1.121$ \\
\hline & 2017 & 1.00 & 9.00 & 11.971 & $5.600 \pm 0.893$ & $-0.398 \pm 0.580$ & $-1.652 \pm 1.121$ \\
\hline & 2018 & 1.00 & 9.00 & 13.924 & $6.067 \pm 0.963$ & $-0.746 \pm 0.580$ & $-1.618 \pm 1.121$ \\
\hline \multirow{5}{*}{ EVIND $(n=16)$} & 2014 & 1.00 & 1.00 & 0.000 & $1.000 \pm 0.000$ & N/A & N/A \\
\hline & 2015 & 1.00 & 2.00 & .163 & $1.188 \pm 0.101$ & $1.772 \pm 0.564$ & $1.285 \pm 1.091$ \\
\hline & 2016 & 1.00 & 2.00 & .063 & $1.938 \pm 0.063$ & $-4.000 \pm 0.564$ & $16.000 \pm 1.091$ \\
\hline & 2017 & 1.00 & 2.00 & .117 & $1.875 \pm 0.085$ & $-2.509 \pm 0.564$ & $4.898 \pm 1.091$ \\
\hline & 2018 & 1.00 & 3.00 & .496 & $1.688 \pm 0.176$ & $0.537 \pm 0.564$ & $-0.643 \pm 1.091$ \\
\hline \multirow{5}{*}{$\begin{array}{l}\text { GOVIND } \quad(\mathrm{n}= \\
15)\end{array}$} & 2014 & 0.00 & 7.00 & 3.552 & $5.533 \pm 487$ & $-2.091 \pm 0.580$ & $4.985 \pm 1.121$ \\
\hline & 2015 & 0.00 & 7.00 & 3.210 & $5.733 \pm 0.463$ & $-2.548 \pm 0.580$ & $7.935 \pm 1.121$ \\
\hline & 2016 & 1.00 & 6.00 & 1.743 & $5.200 \pm 0.341$ & $-2.570 \pm 0.580$ & $7.682 \pm 1.121$ \\
\hline & 2017 & 1.00 & 7.00 & 1.810 & $5.333 \pm 0.347$ & $-2.536 \pm 0.580$ & $8.372 \pm 1.121$ \\
\hline & 2018 & 1.00 & 8.00 & 2.838 & $6.533 \pm 0.435$ & $-2.859 \pm 0.580$ & $9.229 \pm 1.121$ \\
\hline \multirow{5}{*}{$\operatorname{SOCIND}(\mathrm{n}=12)$} & 2014 & 1.00 & 8.00 & 6.788 & $3.333 \pm 0.752$ & $0.894 \pm 0.637$ & $-0.747 \pm 1.232$ \\
\hline & 2015 & 1.00 & 8.00 & 8.205 & $3.750 \pm 0.827$ & $0.440 \pm 0.637$ & $-1.515 \pm 1.232$ \\
\hline & 2016 & 1.00 & 8.00 & 6.568 & $4.250 \pm 0.740$ & $0.328 \pm 0.637$ & $-1.552 \pm 1.232$ \\
\hline & 2017 & 2.00 & 8.00 & 5.720 & $4.583 \pm 0.690$ & $0.211 \pm 0.637$ & $-1.628 \pm 1.232$ \\
\hline & 2018 & 1.00 & 8.00 & 9.152 & $4.333 \pm 0.873$ & $0.043 \pm 0.637$ & $-1.918 \pm 1.232$ \\
\hline
\end{tabular}

Key: $\quad$ Min $=$ Minimum $\quad$ Max $=$ Maximum $\quad$ Mean \pm SE $=$ Mean \pm its Standard Error

Skew \pm SE $=$ Skewness \pm its Standard Error

$\mathrm{N} / \mathrm{A}=$ Not Applicable
Kurt $\pm \mathbf{S E}=$ Kurtosis \pm its Standard Error 
The results of the two-factor analysis of variance of sustainability variables across the years are presented in Table 2 . At $p$-value $<0.05$, the sustainability variables were observed to have a significant effect, that is, there is a significant difference between the sustainability variables across years while yearly variation has no significant effect. The interaction between the yearly variations and sustainability variables was also observed to have no significant effect.

Table 2. Two Factor Analysis of variance of sustainability variables across the years

\begin{tabular}{llllll}
\hline SV & SS & df & MS & F & p-value \\
\hline Corrected Model & $943.221^{\mathrm{a}}$ & 19 & 49.643 & 9.123 & 0.000 \\
Intercept & 5144.199 & 1 & 5144.199 & 945.381 & 0.000 \\
Sustainability variables & 897.049 & 3 & 299.016 & 54.952 & 0.000 \\
Year & 24.429 & 4 & 6.107 & 1.122 & 0.346 \\
Sustainability variables*Year & 22.254 & 12 & 1.855 & 0.341 & 0.981 \\
Error & 1469.179 & 270 & 5.441 & & \\
Total & 7528.000 & 290 & & & \\
Corrected Total & 2412.400 & 289 & & & \\
\hline
\end{tabular}

\begin{tabular}{llll}
\hline Kays: & SV - Source of Variation & SS - Sum of Squares & df - degree of freedom \\
& MS - Mean Squares & F - F statistics & p-value - probability value
\end{tabular}

The observed significance difference inferred in Table 2 is more clearly presented in Table 3 . No significant difference was observed between the five years; 2014 with mean \pm its standard error $3.767 \pm 0.308$, 2015 with $4.118 \pm 0.308,2016$ with $4.297 \pm 0.308,2017$ with $4.348 \pm 0.308$ and 2018 with $4.655 \pm 0.308$. Significant differences were observed between the sustainability variables except for ECOIND and GOVIND that are not significantly different from each other. Based on their mean and standard error, the effect of the environmental variable is as follows in increasing order; ECOIND (5.693 \pm 0.269$)$, GOVIND (5.667 \pm 0.269$)$, SOCIND (4.050 \pm 0.301 ), and EVIND $(1.538 \pm 0.261)$.

Table 3. Post Hoc Test on the effects of sustainability variables and year as a source of variation

\begin{tabular}{llll}
\hline \multicolumn{2}{l}{ Sustainability Variables } & Year & \\
\hline ECOIND & $5.693 \pm 0.269^{\mathrm{c}}$ & 2014 & $3.767 \pm 0.308^{\mathrm{a}}$ \\
EVIND & $1.538 \pm 0.261^{\mathrm{a}}$ & 2015 & $4.118 \pm 0.308^{\mathrm{a}}$ \\
GOVIND & $5.667 \pm 0.269^{\mathrm{c}}$ & 2016 & $4.297 \pm 0.308^{\mathrm{a}}$ \\
SOCIND & $4.050 \pm 0.301^{\mathrm{b}}$ & 2017 & $4.348 \pm 0.308^{\mathrm{a}}$ \\
& & 2018 & $4.655 \pm 0.308^{\mathrm{a}}$ \\
\hline
\end{tabular}

Keys: $\quad$ Data Presentation $=$ Mean \pm Standard Error

Values with different superscripts are significantly different 


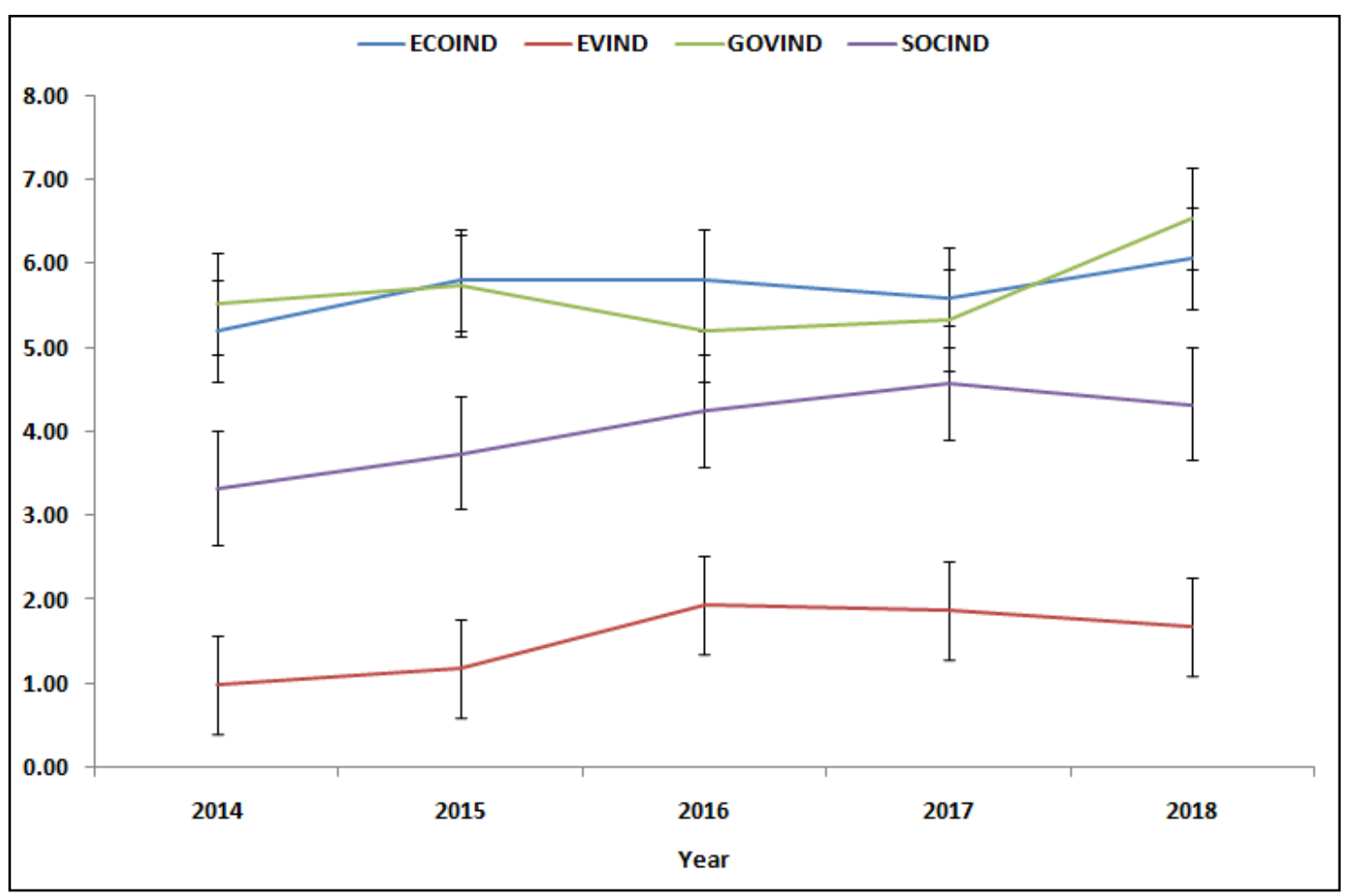

Figure 1. Marginal mean with standard error plot of sustainability variables across year

Figure 1 shows the marginal means with standard error plot of the sustainability variables across the year (2014 2018). It can be seen that EVIND varies differently from the other variables. The plot of ECOIND and GOVIND can be seen to intersect across the year which implies the possibility of a no difference between the two variables across the year. However, a different case can be observed from the plot of SOCIND. SOCIND was observed to vary differently from other variables in the year 2014, 2015 and 2018, while it was observed to intersect with ECOIND and GOVIND (Figure 1).

The observations visualized from Figure 1 were discovered to be reinforced in Table 4 which presents the result of a one-way analysis of variance and its post hoc test conducted on the sustainability variables per year. There was no significant difference between ECOIND and GOVIND in 2014 and 2015 but there exists a significant difference between every other sustainability variable. In 2016, only EVIND was observed to be significantly different from the other sustainability variables while ECOIND, GOVIND, and SOCIND were observed to be similar. The same observation was made in 2017 except for the significant difference observed between GOVIND and SOCIND while the mean of ECOIND was significantly similar to them separately.

Table 4. One Way Analysis of variance of the sustainability variables for each separate year and its Post Hoc Result

\begin{tabular}{llllll}
\hline $\begin{array}{l}\text { Sustainability } \\
\text { variables }\end{array}$ & $\mathbf{2 0 1 4}$ & $\mathbf{2 0 1 5}$ & $\mathbf{2 0 1 6}$ & $\mathbf{2 0 1 7}$ & $\mathbf{2 0 1 8}$ \\
\hline ECOIND & $5.200 \pm 0.937^{\mathrm{c}}$ & $5.800 \pm 0.932^{\mathrm{c}}$ & $5.800 \pm 0.823^{\mathrm{b}}$ & $5.600 \pm 0.893^{\mathrm{b}}$ & $6.067 \pm 0.963^{\mathrm{bc}}$ \\
EVIND & $1.000 \pm 0.000^{\mathrm{a}}$ & $1.188 \pm 0.101^{\mathrm{a}}$ & $1.938 \pm 0.063^{\mathrm{a}}$ & $1.875 \pm 0.342^{\mathrm{a}}$ & $1.688 \pm 0.176^{\mathrm{a}}$ \\
GOVIND & $5.533 \pm 0.487^{\mathrm{c}}$ & $5.733 \pm 0.463^{\mathrm{c}}$ & $5.200 \pm 0.341^{\mathrm{b}}$ & $5.333 \pm 0.347^{\mathrm{b}}$ & $6.533 \pm 0.435^{\mathrm{c}}$ \\
SOCIND & $3.333 \pm 0.752^{\mathrm{b}}$ & $3.750 \pm 0.827^{\mathrm{b}}$ & $4.250 \pm 0.740^{\mathrm{b}}$ & $4.583 \pm 0.690^{\mathrm{b}}$ & $4.333 \pm 0.873^{\mathrm{b}}$ \\
$\quad$ F & $11.793(0.000)$ & $12.405(0.000)$ & $10.136(0.000)$ & 9.532 & $10.000)$ \\
(p-value) & & & & & $1.809(0.000)$ \\
\hline
\end{tabular}

Keys: Data Presentation $=$ Mean \pm Standard Error

Values with different superscripts are significantly different 


\section{Summary and Conclusion}

This study environmental reporting and sustainability reports in oil companies in Nigeria adopted the survey and ex-post-facto research designs. This is because of the nature of the data required. The dependent variable (environmental reporting) was measured with a 56 item sustainability reporting index from GRI. Out of a population of fourteen (14) quoted oil companies in Nigeria, Nine (9) was selected based on the availability and the nature of data needed. From the result obtained from our test of hypotheses of both the one and two way ANOVA, we conclude that there is positive and significant variation between corporate sustainability reporting indicators and the determinant of sustainability reporting in petroleum companies in Nigeria. Our finding corroborates the studies of Nwobu (2017) and Eljayash et al (2012). We recommend that management of oil companies should ensure compliance with the guidelines of corporate sustainability reporting as this portrays good image of their company. This finding implies that there is a shift in sustainability reports of petroleum companies. This study has contributed in reviewing the previous studies and is most current in petroleum companies in Nigeria. It has also shown that petroleum companies are getting concerned about sustainability reports and the environment in which they operate. However, adequate data on environmental and sustainability reports threatened the attainment of the objective of this study, but the researchers were able to overcome this through the rigorous search on the internet and other available documents. Hence, we suggest that further study can be carried out in other sectors of Nigeria's economy or perhaps in other developing nations in the same sector.

\section{References}

Adams, C. A., \& Harte, G. (1998). The Changing Portrayal of the Employment of Women in British Banks and Retail Companies "Corporate Annual Reports". Accounting, Organizations and Society, 23(8), 781-812.

Adegbite, A. A., Amiolemen, S. O., Ologeh, I. O., \& Oyefuga, I. O. (2012). Sustainable development policy and corporate social responsibility in business 251 organizations in Nigeria. Journal of Sustainable Development, 5(6), 83-89. https://doi.org/10.5539/jsd.v5n6p83

Alazzani, A., \& Wan-hussin, W. N. (2013). Global Reporting Intiatives environmental reporting: A study of oil and gas companies. Ecological Indicators, 32, 19-24. Retrieved from www.elsevier.com/locate/ecolind

Asaolu, T. O., Agboola, A. A., Ayoola, T. J., \& Salawu, M. K. (2011). Sustainability reporting in the Nigerian oil and gas sector. In Environmental Management Conference, Federal University of Agriculture, Abeokuta, Nigeria, 12-15 September 2011, pp. 1-24. Retrieved from http://scholar.oauife.edu.ng/sites/default/files/tjayoola/files/238-475-1- sm.pdf

Asogwa, C. K., Ofoegbu, G. N., Nnam, J. I., \& Chukwunwike, O. D. (2019). Effect of corporate governance board leadership models and attributes on earnings quality of quoted Nigerian companies. Cogent Business and Management, 6, 1683124. https://doi.org/10.1080/23311975.2019.1683124

Bebbington, J. (2004). Governance from the Perspective of Social/Environmental Accounting. Social and Environmental Accounting Journal, 24(2), 15-18.

Brown, N., \& Deegan, C. (1998). The public disclosure of environmental performance information - a dual test of media agenda setting theory and legitimacy theory. Accounting and Business Research, 29(1), 21-41. https://doi.org/10.1080/00014788.1998.9729564

Campbell, D. (2000). A longitudinal and cross-sectional analysis of environmental disclosure in UK companies--a research note. The British Accounting Review, 36, 107-17. https://doi.org/10.1016/j.bar.2003.09.001

Campbell, D., Craven, B., \& Shrives, P. (2003). Voluntary social reporting in three FTSE sectors: A comment on perception and legitimacy. Accounting, Auditing and Accountability Journal, 16(4), 558-581.

Central Bank of Nigeria. (2012). Nigerian sustainable banking principles - Central Bank of Nigeria. Abuja, Nigeria: Central Bank of Nigeria. Retrieved from https://www.cbn.gov.ng/out/2012/ccd/circular-nsbp.pdf

Cheema, G., \& Javed, F. (2017). Effect of Corporate Social Responsibility toward green human resource management: mediating role of sustainable environment. Cogent Business \& Management, 4, 1310012. https://doi.org/10.1080/23311975.2017.1310012

Christofi, A., Christofi, P., \& Sisaye, S. (2012). Corporate sustainability: Historical development and reporting practices. Management Research Review, 35(2), 157-172. https://doi.org/10.1108/01409171211195170

Cormier, D., Gordon, I. M., \& Magnan, M. (2004). Corporate environmental disclosure: Contrasting management's perceptions with reality. Journal of Business Ethics, 49, 143-165. 
https://doi.org/10.1023/B:BUSI.0000015844.86206.b9

Crowther, D. (2004). Corporate Social Reporting: Genuine Action or Window Dressing?. In D. Crowther, \& L. Rayman- Bacchus (Eds.), Perspectives on Corporate Social Responsibility (pp. 140-160). Aldershot, UK: Ashgate Publishing Limited.

Cunha, D. R., \& Moneva, J. M. (2016). Environmental Reporting of Global Oil Companies. International Research Journal of Finance and Economics, (158). $\quad$ Retrieved from http://www.internationalresearchjournaloffinanceandeconomics.com

Cyriac, S. (2013). Corporate sustainability reporting practices: A comparative study of practices by Indian and European companies. The Macrotheme Review, 2(6), 38-258. Retrieved from http://macrotheme.com/yahoo_site_admin/assets/docs/4CyMR26.32041008.pdf

Deegan, C. (2002). Introduction: The legitimising effect of social and environmental disclosures-a theoretical foundation. Accounting, Auditing \& Accountability Journal, 15(3), 282-311.

Deegan, C., Rankin, M., \& Tobin, J. (2002). An examination of the corporate social and environmental disclosures of BHP from 1983-1997: A test of legitimacy theory. Accounting, Auditing and Accountability Journal, 15(3), 312-343.

Directory of the Nigerian Stock Exchange. (2015). Listed companies. Retrieved from http://www.nse.com.ng/Issuers-section/listed-securities/listed-companies

Dobbs, S., \& Van Staden, C. (2011). Motivations for corporate social and environmental reporting: New Zealand Evidence. Retrieved from http://www.utas.edu.au/_data/assets/pdf_file/0011/188426/Dobbs_VanStaden.pdf

Eljayash, K. M, James, K., \& Kong, E. (2012). The quantity and quality of environmental disclosure in annual reports of national petroleum companies in middle east and north Africa. International Journal of Economics and Finance, 4(10).

Eljayash, K. M. (2015). Documentation of environmental disclosure practices in the oil companies in the countries of the Arab spring - some evidences from Egypt, Libya and Tunisia. Journal of Economics, Business and Management, 3(10).

Ernst\&Young. (2013). Six growing trends in corporate sustainability. Retrieved from http://www.ey.com/Publication/vwLUAssets/Six_growing_trends_in_corporate_sustainability_2013/\$FILE/Six _growing_trends_in_corporate_sustainability_2013.pdf

Global oil and gas industry association for environmental and social issues. (2015). Membership. Retrieved from http://www.ipieca.org/membership/

Global Reporting Initiative. (2011). Sustainability reporting guidelines version 3.1. Retrieved from https://www.globalreporting.org/resourcelibrary/G3.1-Guidelines-Incl-Technical-Protocol.pdf

Global Reporting Initiative. (2013a). Sustainability reporting guidelines version G4. Retrieved from http://www.globalreporting.org/resourcelibrary/grig4- part1- reporting-principles-and-Standard-Disclosures.pdf

Global Reporting Initiative. (2013b). The external assurance of sustainability reporting. Retrieved from https://www.globalreporting.org/resourcelibrary/GRI-Assurance.pd

Islam, M. A. (2010). Social and environmental accounting research: major contributions and future directions for developing countries. Journal of the Asia-Pacific Centre for Environmental Accountability, 16(2), $27-43$.

Ismail, K., \& Ibrahim, A. H. (2016). Social and Environmental Disclosure in the Annual Reports of Jordanian Companies. Issues in Social and Environmental Accounting, 2, 198-210.

Johl, S. K., \& Khan, P. A. (2019). Nexus of comprehensive green innovation, environmental management system-14001-2015 and firm performance. Cogent Business \& Management, 6, 1691833. https://doi.org/10.1080/23311975.2019.1691833

Jones, H. (2010). Sustainability reporting matters: What are national governments doing about it?. London: Association of Certified Chartered Accountants. Retrieved from http://www.accaglobal.com/content/dam/acca/global/PDF-technical/sustainability-reporting/tech-tp-srm.pdf

Khan, S. N., Hussain, R. I., Ur-Rehman, S., Maqbool, M. Q., Ali, E. I. E., \& Numan, M. (2019). The mediating role of innovation between corporate governance and organizational performance: Moderating role of innovative 
culture in Pakistan textile sector. Cogent Business and Management, 6, 163108. https://doi.org/10.1080/23311975.2019.163108

KPMG. (2007). KPMG International Survey of Environmental Reporting 1999. KPMG Environmental Consulting, DeMeern, The Netherlands.

Kwanbo, M. L. (2011). An assessment of the effectiveness of social disclosure on Earnings per Share in Nigerian public corporations. World Journal of Social Sciences, I(1), 86-106. Retrieved from http://www.wbiconpro.com/313-Lubabah.pdf

Madugba, J. U., Ben-caleb, E., Lawal, A. A., \& Agburuaga, U. T. (2020). Firm size and tax saving behaviour of listed companies in Nigeria. Academic Journal of Interdisciplinary Studies, 9(3).

Martina, E., \& Emma, P. (2016). A study of environmental disclosures in the European oil and gas Industry. Master's thesis in business administration- Accounting. Jonkoping University international business school.

Meek G. K., Roberts, C. B., \& Gray, S. J. (1995). Factors influencing voluntary annual report disclosure by US, UK, and continental European multinational corporation. Journal of International Business Studies, 26(3), 555-572.

Muller, S. (2011). Quantitative sustainability disclosure - An international comparison and its impact on investor valuation. Master's Thesis, Lappeenranta University of Technology, Finland. Retrieved from http://www.doria.fi/bitstream/handle/10024/69887/nbnfife201106101728.pdf?sequence=2

Murray, A., Sinclair, D., Power, D., \& Gray, R. (2006). Do financial markets care about social and environmental disclosure? Further evidence and exploration from the UK. Accounting, Auditing and Accountability Journal, 19(2), 228-255. https://doi.org/10.1108/09513570610656105

Neu, D., Warsame, H., \& Pedwell, K. (1998). Managing Public Impressions: Environmental Disclosures in Annual Reports. Accounting, Organizations and Society, 23(3), 265-282. https://doi.org/10.1016/S0361-3682(97)00008-1

Nwobu, O. A. (2017). Determinants of corporate sustainability reporting in selected companies in Nigeria. A thesis submitted to the department of accounting, college of business and social sciences in partial fulfillment of the requirements for the award of doctor of philosophy (ph.d) degree in accounting.

O’Dwyer, B. (2002). Managerial perceptions of corporate social disclosure: An Irish story. Accounting, Auditing \& Accountability Journal, 15(3), 406-436. https://doi.org/10.1108/09513570210435898

O’Dwyer, B., \& Owen, D. L. (2005). Assurance statement practice in environmental, social and sustainability reporting: A critical evaluation. The British Accounting Review, 37(2), 205-229. https://doi.org/10.1016/j.bar.2005.01.005

O'Dwyer, B., Owen, D., \& Unerman, J. (2011). Seeking legitimacy for new assurance forms: The case of assurance on sustainability reporting. Accounting, Organizations and Society Journal, 36(1), 31-52. https://doi.org/10.1016/j.aos.2011.01.002

Ofoegbu, G. N., Odoemelam, N, \& Okafor, R. G. (2018). Corporate governance board characteristics and environmental disclosure quantity: Evidence from South Africa (integrated reporting) and Nigeria (traditional reporting). Cogent business \& management, 5, 1551510. https://doi.org/10.1080/23311975.2018.1551510

Okoye, A. E., \& Ngwakwe, C. C. (2004). Environmental Accounting: A Convergence of Antecedent Divergence. In A. C. Ezejelue, \& A. E. Okoye (Eds.), Accountancy: Management Companion, Nigeria. Nigeria: Nigerian Accounting Association.

Parker, L. D. (2005). Social and environmental accountability research: A view from the commentary box. Accounting, Auditing \& Accountability Journal, 18(6), 842-860. https://doi.org/10.1108/09513570510627739

Parve, A. K., \& Satirenjit, K. J. (2019). Nexus of comprehensive green innovation, environmental management system 14001-2015 and firm performance. Cogent Business \& Management, 6, 1691833. https://doi.org/10.1080/23311975.2019.1691833

Patten, D. M. (1992). Intra-industry environmental disclosures in response to the Alaskan oil spill: A note on legitimacy theory. Accounting, Organizations and Society, 17(5), 471-475.

Patten, D. M. (2002). The relation between environmental performance and environmental disclosure: A research note. Accounting, Organizations and Society, 27(8), 763-773.

Permatasari, P. (2018). Analysis of Sustainability Reporting Practices in Mining and Oil \& Gas Companies in 
Indonesia (GRI Guideline Approach). The Journal of Social Sciences Research, 2, 483-489.

Schneider, J., Ghettas, S., Merdaci, N., Brown, M., Martyniuk, J., Alshehri, W., \& Trojan, A. (2013). Towards Sustainability in the Oil and Gas Sector: Benchmarking of Environmental, Health, and Safety Efforts. Journal of Environmental Sustainability, 3(3). Retrieved from http://scholarworks.rit.edu/jes/vol3/iss3/6

Securities and Exchange Commission. (2011). Code of Corporate Governance for Public Companies. Nigeria: Securities and Exchange Commission. Retrieved from www.sec.gov.ng/code-of-corporate- governance-.html

Ssekiziyivu, B., Mweigwa, R., Bananuka, J., \& Namusobya, Z. (2018). corporate governance practices in microfinance institutions: Evidence from Uganda. Cogent Business \& Management, 5, 1488508. https://doi.org/10.1080/23311975.2018.1488508

Suchman, M. C. (1995). Managing legitimacy- strategic and institutional approaches. The Academy of Management Review, 20(3), 571-610. Retrieved from https://www.jstor.org/stable/pdf/258788.pdf

Tilt, C. A., Tilling, M. V., \& Davidson, R. (2006). NGO activism via websites. In Australasian Conference on Social and Environmental Accounting Research. Wellington, New Zealand, 22-24 November, pp. 1-12. Retrieved from https://digital.library.adelaide.edu.au/dspace/bitstream/2440/55401/1/hdl_55 401.pdf

Uwaoma, I., \& Ordu, P. A. (2016). Environmental reporting in the oil and gas industry in Nigeria. International Journal of Research in Business Studies and Management, 3(11).

Wilmshurst, T. D., \& Frost, G. R. (2000). Corporate environmental reporting. A test of legitimacy theory. Accounting, Auditing \& Accountability Journal, 13(1), 10-26. https://doi.org/10.1108/09513570010316126

\section{Copyrights}

Copyright for this article is retained by the author(s), with first publication rights granted to the journal.

This is an open-access article distributed under the terms and conditions of the Creative Commons Attribution license (http://creativecommons.org/licenses/by/4.0/). 